\title{
İnformasiya cəmiyyəti şəraitində Azərbaycan vətəndaşlarının identifikasiyası problemləri və həlli yolları haqqinda
}

\author{
Rasim Oliquliyev ${ }^{1}$, Yedgar Cəfərov ${ }^{2}$, Ofruz Qurbanova ${ }^{3}$ \\ AMEA İnformasiya Texnologiyaları İnstitutu, Bak1, Azərbaycan \\ Idirector@iit.science.az, ${ }^{2}$ yedgar@yandex.ru, ${ }^{3}$ afruz1961@gmail.com
}

\begin{abstract}
Xülasə_ Məqalə vətəndaşların adlandırılması sistemi və milli identiklik məsələlərindən bəhs edir. Azərbaycanda vətəndaşların adlandırılması ilə bağlı mövcud problemlər araşdırılmışdır. Qloballaşma dövründə, informasiya cəmiyyəti şəraitində bu problemlərin doğurduğu neqativ hallar nəzərdən keçirilmişdir. Azərbaycan ad və soyadlarının, bununla bağlı tarixi ənənələrin, adlandırma strukturunun ətraflı təhlili aparılmışdır. Bu sahədə xarici təcrübə araşdırılaraq problemlərin həlli istiqamətində təkliflər irəli sürülmüşdür.
\end{abstract}

Açar sözlor-ad; soyad; ata adı; toxollüs; loqəb; adlandırma; ad sistemi; milli identiklik;

\section{GİRIŞ}

Xalqın yaşam tərzinin tərkib hissəsi olan insan adlarında xalqların həyatı, keçmişi, inancları, arzu və xəyalları, yaradıcılığ1, sosial mühiti, əlaqələri və s. əks olunur [1]. Azərbaycanın qlobal informasiya məkanına sürətlə inteqrasiyası bir çox taleyüklü məsələlər kimi ad və soyad sistemi və milli identiklik məsələlərinin araşdırılmasını da zəruri edir. Məlum olduğu kimi, qloballaşma prosesi bütün müsbət cəhətləri ilə yanaşı, xalqları öz milli xüsusiyyətlərini tədricən itirmək təhlükəsi ilə üz-üzə qoyur. Belə bir şəraitdə milli identikliyin qorunması, hüdudsuz və xaotik qlobal informasiya məkanında xalqın öz milli mənsubiyyətini asanlıqla ifadə edə bilməsi üçün təkmil, dayanıqlı və səmərəli mexanizmlər formalaşdırılmalıdır. Ümumiyyətlə, xalqların milli identikliyini təmin edən əsas əlamətlər bunlardır: xarici görünüş, ad, vətəndaşlıq, dil, inanc, adət-ənənə, mətbəx, musiqi və s. Müasir dünyamızın əsas reallıqlarından birinə çevrilmiş virtual məkanda hər bir azərbaycanlı üçün elə bir ad mühiti yaradılmalıdır ki, bütün dünya azərbaycanlılarının milli identikliyini təmin etsin, bizi başqa xalqlardan fərqləndirə bilsin.

\section{AZӘRBAYCANDA ADLANDIRMA SISTEMININ FORMALAŞMASI TARIXİ}

Tarixin ibtidai dövrlərindən başlayaraq sosialkommunikativ ehtiyac kimi hər bir xalqın özünəməxsus adlandırma ənənələri formalaşmışdır. Qədim türklərin, o cümlədən azərbaycanlıların da adlandırma sistemi spesifik xüsusiyyətlərə malikdir. Qədim türkdilli abidələr, o cümlədən "Orxon-Yenisey" kitabələri, M.Kaşğarinin "Divani-lüğət-it- türk" əsəri, "Kitabi-Dədə Qorqud" dastanları və bir sıra etnoqrafik məlumatlar türk xalqlarında adlandırma ənənələrinin qədimliyini və sistemliliyini göstərir [2]. Azərbaycanın adlandırma sisteminin təşəkkülü və inkişafı cədvəl 1-də verilmişdir.

Qeyd edək ki, müxtəlif xalqlarda nəsil adı ilə adlandırma ənənələri nə qədər qədim olsa da, "familiya (soyad)" termininin özü eramızın III-IV əsrlərində yaranmışdır. Latın dilində "ailə”, "qohum-əqrəba", qulluqçular da daxil olmaqla bütün evdəkilərin cəmini bildirən «soyad» ictimai-tarixi hadisə kimi IV əsrdə İngiltərədə, X-XI əsrlərdə İtaliyada, XV-XVI əsrlərdə Danimarkada, XIV-XVIII əsrlərdə Macarıstanda, XVIII əsrdə Şotlandiya və İrlandiyada yayılmışdır. Soyad 1926-1934-cü illərdə Mustafa Kamal Atatürk tərəfindən Türkiyədə, təxminən eyni tarixdə İranda, 50-ci illərdə Misirdə, 1959-cu ildə Tunisdə rəsmiləşdirilmişdir [3].

Təşəkkül tapdığı ilk çağlardan yüksək sosial status nişanəsi, zadəganlıq göstəricisi sayılması soyadlara marağın artmasına və onların kütləviləşməsinə böyük təsir göstərmişdir. İlk vaxtlar soyadlardan adi insanlar deyil, daha çox zadəganlar istifadə edirdilər. Hətta qədim İngiltərədə yoxsul ailədən olan oğlanın zadəgan ailəsindən olan qızla ailə qurarkən, q1zın soyadını götürməsi ənənəsi vardı [2].

Rus ad sistemində isə soyad 1703-cü ildə I Pyotrun hakimiyyəti zamanında tətbiq olunmuş və əsasən dövlət xadimlərinə, knyaz və mülkədarlara verilmişdi. I Pyotr özü zadəganları fəxri ad kimi soyadlarla mükafatlandırırdı. Rusiyada soyadların formalaşmasında türk mənşəli rus boyarlarının böyük rolu olmuşdur. Ona görə, indi də rus adlandırma sistemində türk mənşəli soyadlar əhəmiyyətli yer tutur [4].

XIX əsrə doğru Rusiyada cəmiyyətin sosial inkişafinın təsiri ilə soyadlardan istifadə meyli tədricən kütləviləşdi. XIX əsrin sonu - XX əsrin əvvəllərində Rusiya imperiyasının tərkib hissəsi olan Azərbaycanda rəsmi sənədləşmə işlərinin rus dilində aparılması və bu zaman vətəndaşların soyadının ənənəvi qaydada, - oğlu - qızı, - uşağı sonluqları ilə deyil, ov/-yev, -ova/-yeva sonluqlarından istifadə etməklə rus soyadlarına bənzər onomastik vahidlərlə qeyd edilməsi xalqımız arasında bu cür soyadların süni formada yayılmasına rəvac verdi. Həmin dövrdə Azərbaycanda savadsızlığın kütləvi 


\section{“Informasiya tohlükosizliyinin aktual multidissiplinar elmi-praktiki problemlori” \\ V respublika konfransl, 29 noyabr 2019-cu il}

xarakter daşıması da -ov/-yev, -ova/-yeva sonluqlarının geniş yayılmasına əlverişli şərait yaratdı [5].

CODVӘL I. Azərbaycan milli adlandırma sisteminin inkişaf tarixi

\begin{tabular}{|c|c|}
\hline $\begin{array}{l}\text { III -V } \\
\text { əsrlərdən müasir } \\
\text { dövrə kimi } \\
\quad \text { (Türk } \\
\text { adlandırma } \\
\text { sistemi) } \\
\end{array}$ & $\begin{array}{l}\text { Ad və -oğlu, -qızı sonluqları } \\
\text { Bu sonluqlar insanın valideynlərini bildirir: } \\
\text { Məsələn: Ulaş oğlu Salur Qazan; Bəybecan q1zı } \\
\text { Banıçiçək; Dirsə xan oğlı Buğac }\end{array}$ \\
\hline $\begin{array}{l}\text { VII-XVII } \\
\text { əsrlər } \\
\quad \text { (Orəb } \\
\text { adlandırma } \\
\text { sistemi) }\end{array}$ & $\begin{array}{l}\text { Ad və nisbə (-i/-vi ) } \\
\text { Bu sonluq insanın aid olduğu coğrafi məkanı } \\
\text { bildirir. Məsələn: Xaqani Şirvani, Nəsirəddin Tusi, } \\
\text { Məhsəti Gəncəvi, Qətran Təbrizi } \\
\text { Ad və künyə (əbu, ümm) } \\
\text { Bu sonluqlardan əbu - atası, ümm anası mənasını } \\
\text { verərək insanın valideynlik statusuna işarə edir. } \\
\text { Məsələn: Obu İmran (İmranın atası), Ümm Gülsüm } \\
\text { (Gülsümün anası), Obu Reyhan (Reyhanın atası) } \\
\text { Ad və nəsəb (ibn) } \\
\text { Oğlu mənasını daşıan bu sonluq insanın atasının } \\
\text { adını bildirir. Məsələn: İbn Sina (Sinanın oğlu), İbn } \\
\text { Haldun (Haldunun oğlu) }\end{array}$ \\
\hline $\begin{array}{l}\text { XIX əsrdən } \\
\text { müasir dövrə kimi } \\
\quad \text { (Fars } \\
\text { adlandırma } \\
\text { sistemi) } \\
\end{array}$ & $\begin{array}{l}\text { Ad və -zadə sonluğu } \\
\text { Bu sonluq fars dilində "törənmiş" mənası verərək } \\
\text { insanın valideylərini, nəslini bildirir. } \\
\text { Məsələn: Oli bəy Hüseynzadə, Әzizə Cəfərzadə. }\end{array}$ \\
\hline $\begin{array}{l}\text { XX əsrdən } \\
\text { müasir dövrə kimi } \\
\quad \text { (Rus } \\
\text { adlandırma } \\
\text { sistemi) }\end{array}$ & $\begin{array}{l}\text { Ad və -ov2-yev2;-ski2; -oviç, -ovna, və s. } \\
\text { sonluqları } \\
\text { Bu sonluqlardan -ov, -yev mənşə etibarilə “oğlu" } \\
\text { mənası verərək, insanın atasının adını bildirir. } \\
\text { Məsələn: Yusif Məmmədəliyev, Әşrəf Hüseynov, } \\
\text { Nəsibə Zeynalova. } \\
\text { Rus soyad sisteminə polyaklardan keçmiş -ski } \\
\text { sonluğu şəxsin aid olduğu məkanı işarələyir. } \\
\text { Məsələn: Hüseyn Orəblinski, Hüseynqulu Sarabski, } \\
\text { Ohməd Ağdamski } \\
\text { Rus adlandırma sistemi üçün xarakterik olan } \\
\text { oviç, -ovna kimi sonluqlar soyad bildirməsə də, ata } \\
\text { adının göstəricisi kimi, bəzən azərbaycanlı adlarında } \\
\text { da istifadə olunur: Mamed Rəhmanoviç və s. }\end{array}$ \\
\hline $\begin{array}{l}\text { XX əsrin 80- } \\
\text { ci illərinin } \\
\text { sonlarından } \\
\text { müasir dövrə kimi } \\
\text { (Müasir soyad } \\
\text { sistemi) }\end{array}$ & $\begin{array}{l}\text { Ad və -lı4; -xanlı/-bəyli, sonluqsuz; -ov2- } \\
\text { yev2; } \\
\text {-zadə; -gil;-soy; -oğlu-qızı; -ski2, -i, -vi } \\
\text { sonluqları }\end{array}$ \\
\hline
\end{tabular}

Ötən əsrin 30-cu illərində, Stalin irticası zamanı süni familiyalaşdırma meyli xüsusilə geniş vüsət aldı. Yüksək informativ milli identiklik gücünə malik -oğlu, -qızı kimi soyad sonluqları tədricən sıradan çıxarılaraq və ata adından sonra yazılaraq yalnız cins mənsubiyyətini ifadə etməklə məhdudlaşdı [6].

Azərbaycanın dövlət müstəqilliyinin bərpasından q1sa müddət sonra bu sahədə vəziyyətin nizamlanması məqsədilə Milli Məclisin «Azərbaycan Respublikası vətəndaşlarının soyadlarının dövlət dilinə uyğunlaşdırılması»» haqqında 2 fevral 1993-cü il tarixli qərarına əsasən, Azərbaycan vətəndaşlarına soyadlarındakı -ov/-yev, -ova/-yeva sonluqlarını «zadə», -l14, «oğlu», «q1zı» sonluqları ilə əvəz etmək və yaxud öz soyadlarını sonluqsuz yazmaq imkanları verilmiş, Nazirlər Kabinetinin 12 may 2011-ci il tarixli qərarı ilə "Adın, ata adının və soyadın verilməsi və dəyişdirilməsi Qaydaları" təsdiqlənmişdir. Bununla belə mövcud reallıq, cəmiyyətimizdə adlar və soyadlar sisteminin hələ tam nizama düşmədiyini və qlobal şəraitdə xalqımızın milli identikliyi ilə bağlı yeni problemlərin ortaya çıxdığını göstərir [7].

Müstəqillik illərində, xüsusilə dünyaya yeni gələn körpələrin soyadlarında -ov/-yev, -ova/-yeva sonluqlarının çəkisi xeyli azalmışdır [8]. Amma bunun bir çox hallarda "zadə" və sonluqsuz formalardan istifadə meylinin artması hesabına baş verməsi, eyni zamanda -ov/ -yev, -ova/ -yeva sonluqlarının hələ də qalması bu cür soyadları daşıyan vətəndaşlarımızın qlobal mədəniyyət müstəvisində digər türkdilli xalqlardan və başqa müsəlman ölkələrinin vətəndaşlarından fərqləndirilməsində, identifikasiya olunmasında ciddi çətinliklər yaradır. Nəzərə almaq lazımdır ki, bizim istifadə etdiyimiz adların əksəriyyəti, eləcə də bəzi soyad sistemləri bu xalqlarla müştərəkdir. Sonluqsuz formada yaradılmış soyadlar isə türk və müsəlman dünyasında xeyli işləkdir. Ona görə də bu formalar beynəlxalq aləmdə xalqımızın nümayəndələrinin identifikasiya olunmasında çox ciddi qeyri-müəyyənlik yaradır. Digər tərəfdən, Azərbaycan Respublikası vətəndaşlarına verilən ümumvətəndaşlıq, xidməti, diplomatik pasportlarda, eləcə də beynəlxalq statuslu sürücülük vəsiqələrində, dənizçilik sənədlərində və s. ingiliscə -oğlu, -qızı sözlərinin yazılmaması, üstəlik ata adının ingilis dilində göstərilməməsi vəziyyəti xüsusilə çətinləşdirir. Digər tərəfdən qlobal kommunikasiya mühitində, Azərbaycanda və ölkə sərhədlərindən kənarda əcnəbilərin vətəndaşlarımıza konkret ad komponenti ilə müraciətdə çətinlik çəkmələri, teztez komponentləri qarışıq salmaları müşahidə edilir. Bundan başqa, beynəlxalq mühitdə şəxsin milli identifikliyini müəyyən edən əsas göstəricilərdən biri olan ata adı itmiş olur. Eyni zamanda, bu anormal hal milli mentalitetimizə görə hər övlad üçün müəyyən mənada mənəvi diskomfortluq da yaradır.

\section{MILLİ ADLANDIRMA SİSTEMININ STRUKTURU}

Hazırda mövcud qanunvericilik aktlarının tətbiqi nəticəsində ad və soyadların seçilməsi və qeydiyyatı prosesi xeyli təkmilləşdirilsə də, ad və soyadların qeydiyyatı prosesində müəyyən problemlər hələ də qalmaqdadır. Adlandırma sistemi müxtəlif xalqlarda fərqli olur. Azərbaycanda adlandırma sistemi biradlılıqdan çoxadlılı̆̆a doğru inkişaf etmişdir [5]. Məsələn, Tural (biradlı), Tural Oli oğlu (iki adlı), Tural Đli oğlu Məmmədli (üçadlı). Kənd, tayfa, icma çevrəsində onlara bir ad kifayət edirdi. İnsanın əlavə identik əlamətlərlə başqalarından fərqləndirilməsinə ehtiyac qalmırdı. Bu mühitdə eyniadlı şəxslər meydana çıxdıqda isə onları bir-birindən fərqləndirmək üçün ayamalardan, ləqəblərdən istifadə edilirdi. Adətən, məşğul olduğu sənətin adını insana qoyur, yaxud onun hansısa fiziki əlamətindən, fərdi keyfiyyətindən ləqəb yaradırdılar (məs: Dəmirçi, Pinəçi, 


\section{“Informasiya tohlükosizliyinin aktual multidissiplinar elmi-praktiki problemlori” \\ V respublika konfransl, 29 noyabr 2019-cu il}

Uzun, Keçəl, Qara, Sarı, Kürən və s.). Amma fərdlər geniş məkanda, qəsəbə, şəhər çevrəsində sosial əlaqələrə, gündəlik birgə yaşayış, iş, təhsil və s. mühitinə daxil olub onlarla eyni adı daşıyan başqaları ilə qarşılaşdıqca yeni fərqləndirici informativ əlamətlərin yaranması ehtiyacı ortaya çıxdı. Beləliklə ata adı, soyad hesabına ad komponentlərinin sayı artd1.

Azərbaycan Respublikasının müvafiq qanunvericiliyi hazırda vətəndaşın yalnız bir adla, eləcə də ləqəblərlə, təxəllüslərlə qeydiyyata alınmasına imkan vermir. Belə ki, Azərbaycan Respublikası Mülki Məcəlləsinin 26.1-ci, eləcə də "Adın, ata adının və soyadın verilməsi və dəyişdirilməsi Qaydaları"nın 1.3-cü maddəsinə əsasən, hər bir fiziki şəxsin adı addan, ata adından və soyaddan ibarətdir [9].

Ofsuslar olsun ki, müvafiq normativ-hüquqi aktlarda təsbit edilmiş bu dəqiq ardıcıllığa - ad/ata adı/soyad rəğmən müxtəlif təşkilatların gündəlik fəaliyyətində aparılan sənədləşmə zamanı həmin ardıcıllıq pozulur və bu sahədə milli identiklik modelinin əsası olan dəqiq, stabil milli adlandırma sistemi formalaşdırılmır. Məsələn, Azərbaycan Respublikasının vətəndaşlarına verilən şəxsiyyət vəsiqələrində soyad/ad/ata adı ardıcıllığından istifadə olunur. Digər rəsmi sənədlərdə də bu komponentlər yerini dəyişir, ad, ata adı, soyad ardıcıllığına əməl edilmir, inisial yazılarından istifadə olunur, şəxsin kimliyini müəyyən etmək çox çətinləşir, bəzən heç mümkün olmur. Bir şəxsin adlandırılmasında qeyd olunduğu, Azərbaycan əlifbası və xarici dillərin əlifbaları arasında qeyri-müəyyənlik üçün şərait yaradan çoxvariantlılıq nümunələrinə diqqət yetirək:

Rəhimova Afaq Həsən q1zı;
1. Afaq Həsən q1zı Rəhimova;
2. Afaq Rəhimova Həsən q1z1;
3. A.H.Rəhimova;
4. Rəhimova A.H.;
5. Afaq Rəhimova;
6. Rəhimova Afaq;
7. A.Rəhimova;
8. Rəhimova A.;
9. Afaq H.Rəhimova.

Belə çoxvariantlılıq beynəlxalq kommunikasiya mühitində fərdin milli identikliyini daha da çətinləşdirir. Üstəlik bura xüsusi adların qeyd olunduğu Azərbaycan əlifbası və xarici dillərin əlifbaları arasında transliterasiya ilə bağlı problemləri də əlavə etsək (məsələn, ingilis dilinə transliterasiya zamanı dilimizdəki müvafiq sait və samitlərin (ə - e, a; q - g; x kh və s.) dəyişdiyini nəzərə alsaq) vəziyyətin necə mürəkkəb şəkil aldığını görərik.

Xalqların ad sistemində heç bir hal, təbii ki, təsadüfən yaranmır və bu cür nizamsızlığın da tarixi-sosial kökləri vardır. Məsələn, doğum evində yenicə dünyaya gəlmiş uşaq hələ adı olmadığından başqa körpələrlə qarışıq düşməməsi üçün atanın, yaxud ananın soyadı ilə identifikasiya edilir, beləliklə soyad önə keçir. Yaxud təhsil illərində şagirdlərin, yaxud tələbələrin qeydiyyatının aparıldı̆̆ davamiyyət jurnallarında adlandırma qeydi üçün müəyyən edilmiş yer məhdud olduğundan, bəzən sadələşdirmə zərurəti ilə soyadlar bütöv, ad və ata adları isə baş hərflərin inisialları ilə yazılır. Amma bütün hallarda nəzərə almaq lazımdır ki, ad/ata adı/soyad ardıcıllığı tarixi təkamül prosesinin özünün ortaya çıxardığı bir identifikasiya modelidir. Ad sistemimizdo müxtəlif təsirlərlə yaranmış nizamsızlığın aradan qaldırılmasına, ad/ ata adı/ soyad ardıcıllığının dəqiq norma kimi qəbul olunmasına və bütün sənədləşmələrdə, elektron resurslarda adların vahid struktur üzrə yazılmasının təmin edilməsi hesabına sabit milli standartların möhkəmləndirilməsinə indi çox böyük ehtiyac vardır.

Hazırda ölkəmizdə formalaşmaqda olan e-dövlət mühitində ayrı-ayrı elektron reyestrlərdə vətəndaşların identifikasiya olunması çox böyük çətinliklərlə üzləşir. Belə ki, vətəndaşa məxsus FIN (fərdi identifikasiya nömrəsi) kodu altında müxtəlif variasiyalarda yazılmış ad/ata adı/ soyadları toplamaq lazım gəlir. $\mathrm{Bu}$ isə çox çətin, böyük zəhmət tələb edən prosesdir. Bəzən isə onları bir FIN kod altında identifikasiya etmək, ümumiyyətlə, mümkün olmur. Bu zaman şəxsin digər əlamətlər üzrə axtarılması zərurəti meydana çıxır. Elektron sistemlərdə isə belə dəqiq bir intellektual imkan olmadığından bu, çox vaxt aparır, sorğular göndərilir, digər qurumların resurslar1 cəlb olunur, bəzən də obyektiv və subyektiv səbəblərdən axtarışlar yanlış nəticələr verir. Bundan başqa, şəxslərin ad, ata adı və soyadının yazılışındakı müxtəliflik internet axtarış sistemlərində konkret şəxslərlə bağlı aparılan axtarışların nəticələrində natamamlıq, qeyri-müəyyənlik və s. yaradır. Nəzərə alsaq ki, transliterasiya problemi hələ də mövcuddur, onda problem daha qabarıq şəkildə özünü büruzə verir.

\section{MILLİ ADLANDIRMA SISTEMININ PSIXOLINQVISTIK ASPEKTLORİ}

Yuxarıda qeyd olunanlarla yanaşı, ayrı-ayrı şəxsiyyətlərin həyat və fəaliyyəti, öz ad və soyadlarına qazandırdıqları tarixi mənalarla simvollaşan, eləcə də sosial-mədəni status, şöhrət, nüfuz və s. assosiasiyaları yaradan ad komponentləri vardır. Həmin komponentlərin sırasının pozulması onların ifadə etdiyi assosiativ mənaya da xələl gətirir.

Məsələn, Üzeyir Hacıbəyli, Rəşid Behbudov, Həzi Aslanov, Mirzə İbrahimov ardıcıllığının insan təfəkkürünə ötürdüyü psixoloji informasiya Hacıbəyli Üzeyir, Behbudov Rəşid, Aslanov Həzi, İbrahimov Mirzə ardıcıllığının doğurduğu təsəvvürlə eyni deyildir.

Bir fərd böyüyüb şəxsiyyətə çevrildikcə ona müraciət forması da dəyişir. Uşaq bağçası, məktəb, ali məktəb, hərbi 


\section{“Informasiya tohlükosizliyinin aktual multidissiplinar elmi-praktiki problemlori” \\ V respublika konfransl, 29 noyabr 2019-cu il}

xidmət və s. dövründə fərdin kimliyi qanunla qeyd olunduğu kimi ad/ata adı/soyad ardıcıllığı ilə yox, tərsinə, yəni soyad/ad/ata adı ardıcıllığı ilə qeyd olunur. Omək fəaliyyətinə başlayaraq ictimaiyyət arasında tanındıqca, yaşa dolduqca ad soyaddan önə keçir.

Ad, ata adı və soyadların vahid milli standartının müəyyənləşdirilməsini zəruri edən digər mühüm bir amil də vardır. Məlum olduğu kimi, hazırda Azərbaycan qanunvericiliyi ölkə vətəndaşlarına şəxs $\mathrm{ad}$ və sonluqsuz soyad (Rəsul Rza), yaxud təxəllüs (Səməd Vurğun) və ya oğlu-q1zı sonluqları ilə yaradılmış soyadlarla (Emin Sabitoğlu) qeydiyyata alınmaq imkanı verir. $\mathrm{Bu}$ formalardan istifadə çoxaldıqca ikinci komponentin hansı məna daşıdığını, yəni ikikomponentli şəxs adı, həmin şəxsin adının bir hissəsi, ata adı, nəsil adı, yoxsa təxəllüs olduğunu müəyyənləşdirməkdə, son nəticədə isə fərdi eyniləşdirməkdə çətinliklər yarana bilər. Məsələn, görkəmli Azərbaycan şairi Məmməd Arazın həyat və yaradıcılığı ilə tanış olmayan şəxs bu ad və təxəllüsə ilk dəfə rast gələrkən, onun hansı hissəsinin ad, hansı hissəsinin isə təxəllüs olduğunu aydınlaşdırmaqda çətinlik çəkəcək. Ona görə də adlandırma sistemində komponentlərin hər birinin yeri dəqiq göstərilməlidir ki, gələcəkdə bu cür çətinliklər ortaya çıxmasın.

\section{BEYNӘLXALQ TӘCRÜBӘDӘ ADLANDIRMA SISTEMI}

Azərbaycanda vətəndaşların bütün sənədlərdə qeydiyyatı prosesinin ad/ata adı/soyad, ata adının yazılması zəruri olmadıqda isə ad/soyad ardıcıllığına əsaslanan dəqiq, vahid standart üzrə həyata keçirilməsi beynəlxalq təcrübəyə də uyğun olardı. Belə ki, bir sıra ölkələrdə ilkin ad (ing. first name), orta ad (ing. middle name) və son ad (ing. last name) komponentlərindən təşkil olunmaqla üçkomponentli adlandırma modellərindən istifadə edilir. Bu adların mahiyyəti mədəniyyətlərdən asılı olaraq dəyişir.

İlkin ad (first name). İlkin ad doğularkən şəxsə verilmiş addır. Azərbaycanın milli adlandırma sistemində olduğu kimi bütün başqa xalqlarda da hər bir şəxsin ilkin adı olur.

Orta ad (middle name). Qərb mədəniyyətinə görə, bəzən uşağa bir deyil, iki ad verilir. Bir sıra hallarda isə hətta üç ad qoyulmasına da rast gəlinir. Adətən, ikinci ad atanın, yaxud babanın, nənənin və ya ananın şərəfinə qoyulur və bu "middle name" kimi işlənir. Middle name şəxsə verilmiş adla yanaş1, soyadın da tərkibində ola bilər. İngiltərədə, Avstriyada, Kanadada, Yeni Zelandiyada, ABŞ-da əcdadların (ata, baba, ana, nənə) şəxs adlarından (ing. forename) onların şərəfinə çox tez-tez middle name kimi istifadə olunur [10].

Danimarkada və Norveçdə isə "middle name" soyad anlamı daşıyır. Middle name kimi ananın qızlıq soyadı, yaxud əcdadlardan hansısa birinin son adı seçilə bilər. Middle namelərin bir neçə komponentdən ibarət olması mümkündür.
Amma komponentlərinin sayı ikidən çox olan middle namelərdən istifadə təcrübəsi xarakterik deyildir. Filippində middle name kimi, əsasən, ananın qizlıq familiyasından istifadə olunur. ABŞ-da middle name-dən tez-tez abbreviatura formasında istifadə edilir. Məsələn, Mary Lee Bianchi - Mary L. Bianchi və s. [11].

Tərkibində middle name-lər olan ad komponentlərindən istifadə təcrübəsi Türkiyədə də geniş yayılmışdır: Ali Qalib İgit, Huseyn Gürhan Tuncer, Orhan Şaiq Gökyay, Necib Fazil Kisakürek və s.

Azərbaycanda da bu cür adlandırma komponentlərinə, az da olsa, təsadüf edilir: Ceyhun-Təyyar Paşayev, Həmzə Nihad Həmidov, Oli Rza Xələfli və s. Bu cür ad modellərinin ortaya çıxmasında Türkiyə mədəniyyətinin təsiri istisna olunmamalıdır.

Son ad (last name və ya surname). Son ad şəxsin konkret bir ailəyə, nəslə mənsubluğunu bildirən ad komponentidir. Last name ifadəsinin sinonimləri soyad, yaxud ailə adıdır. Bu mənada last name-ləri soyadlar kimi nəzərdən keçirmək olar.

\section{ADLANDIRMA SISTEMİ İLə BAĞLI TEXNIKI HOLLOR}

Artıq dünyanın bir çox ölkələrində olduğu kimi, Azərbaycanda da biometrik pasportların və yeni nəsil şəxsiyyət vəsiqələrinin verilməsinə başlanmışdır. Biometrik pasport - Beynəlxalq Mülki Aviasiya Təşkilatının (ing. International Civil Aviation Organization, ICAO) müəyyən etdiyi yüksək texnologiya və təhlükəsizlik elementləri əsasında hazırlanır [10]. Bu pasportlarda adlandırma ilə bağlı texnikihüquqi standartlar ICAO-nun "Maşın oxuya bilən səfər sənədləri” (Machine Readable Travel Documents) üzrə təlimatı əsasında tənzimlənir [12].

Təlimata uyğun olaraq biometrik pasportun iki zonası var: 1) Vizual yoxlama zonası; 2) Maşının oxuduğu zona. Pasportda titulları, akademik dərəcələri, fəxri adları, mükafatları, irsi statusları və s. bildirən sözönləri və şəkilçilərdən, rəqəmlərdən, əsasən, istifadə olunmur. $\mathrm{Bu}$, yalnız müvafiq dövlət idarəsi tərəfindən onların adın ayrılmaz bir hissəsi olduğu rəsmi şəkildə təsdiqləndikdə mümkündür.

Biometrik pasportun maşın oxuyan zonasında da soyad əsas, şəxsin öz adı ikinci dərəcəli ad sayılır, əsas və ikinci dərəcəli adlar bir-birindən "<" işarəsi vasitəsilə ayrılır. Bu zonada adın tərkib hissəsi kimi rəqəmlərdən, apastrof, defis, vergül kimi durğu işarələrindən istifadə olunmur.

Vizual yoxlama zonasında isə dövlətlər məlumatların daha da dəqiqliyi, fərdin identifikasiyası məqsədilə öz milli işarələrindən, yaxud latın əlifbasına daxil olmayan hər hansı başqa işarələrdən istifadə edə bilərlər. Ona görə də bəzi hallarda maşının oxuduğu zonadakı adlar tərtibat baxımından vizual yoxlama zonasındakı adlarla tam üst-üstə düşməyə bilər. 


\section{"Informasiya tohlükssizliyinin aktual multidissiplinar elmi-praktiki problemlori” \\ V respublika konfransl, 29 noyabr 2019-cu il}

Göründüyü kimi, biometrik pasportların və yeni nəsil şəxsiyyət vəsiqələrinin vizual yoxlama zonasında xalqımızın milli identikliyinin əsas antroponimik əlaməti kimi çıxış edən "oğlu” və "qızı" sözlərinin yazılmasından ötrü də heç bir hüquqi və texniki məhdudiyyət yoxdur. "fon", "Mc", "de la" sözönləri kimi azərbaycanlılara xas "oğlu”, "q1zı” sözlərindən də pasportlarda sonluq kimi istifadə edilə bilər. Bu sonluqlar beynəlxalq səviyyədə çox böyük əhəmiyyət daşıyır. Beynəlxalq aləmdə bəzən şəxsin digər yaxın xalqlarla müqayisədə milli identikliyini təmin edən yeganə indikator rolunu oynayır.

\section{NӘTİCӘ}

Aparılan təhlillər əsasında Azərbaycan Respublikasında adlandırma sisteminin təkmilləşdirilməsi və həm ölkə daxilində, həm də qlobal informasiya məkanında xalqımızın milli identikliyinin təmin olunması məqsədilə aşağıdakı təkliflər irəli sürülür:

Ölkə üzrə bütün sənədləşmə və qeydiyyat işlərinin ardıcıllığın saxlanması şərtilə aşağıdakı formatlar üzrə aparılması:

- Komponentlərin hər birinin yazılması zəruri olduğu hallarda ad/ata adı/soyad formatı;

- Ata adının yazılmasının zəruri olmadığı hallarda ad/soyad format1;

- Ata adı inisialının göstərilməsinin zəruri olduğu hallarda: ad/ata adının ilk hərfi/soyad formatı;

- Beynəlxalq aləmdə fərdin milli identifikliyinin təmin olunmas1 məqsədilə Azərbaycan Respublikas1 vətəndaşlarına verilən biometrik pasportlarda və yeni nəsil şəxsiyyət vəsiqələrində həm Azərbaycan, həm də ingilis dilində addan sonra ata adının daxil edilməsi və mütləq “oğlu” və "q1zı" sözlərinin əlavə olunması;

- Milli transliterasiya standartlarının qəbul olunması, biometrik pasportlarda və yeni nəsil şəxsiyyət vəsiqələrində müvafiq qaydada istifadə məqsədilə adlandırma sisteminə transliterasiya standartlarının (cədvəllərinin) (az-en, en-az) əlavə olunmas1;

- Milli adlandırma standartları ilə bağlı texniki məsələlərin optimal həlli üçün Beynəlxalq Mülki Aviasiya Təşkilatı ilə müzakirələrin təşkili.

$\mathrm{Bu}$ gün yeni inkişaf mərhələsində tarixi nailiyyətlər qazanan, qlobal proseslərin fəal subyektinə çevrilən Azərbaycan dövlətinin adlar vasitəsilə xalq1n milli identikliyinin ifadəsi məsələsini yenidən nəzərdən keçirməsi, Azərbaycançılıq ideologiyası çərçivəsində, tarix və müasirlik işı̆̆ında bu problemin optimal həlli yollarının tapılması xalqımızın gələcəyinə, informasiya cəmiyyətinin inkişafına, milli şüurun, özünüdərk hissinin daha da yüksəlişinə töhfə olard1.

\section{ISTINADLAR}

[1] Л.Э.Аблитарова, “Формирование имен и фамилий у различных народов, проживающих на территории Крыма”, Современная филология: материалы IV Междунар. науч. конф., г. Уфа, 2015, с. 19-21.

[2] H.Ә.Həsənov, "Familiya sosial-ictimai hadisə kimi”, Azərbaycan onomastikası problemlərinə həsr olunmuş III elmi-nəzəri konfransın materialları, Bakı, APU, 1990, s. 9-11

[3] A.Paşa, "Azərbaycan antroponimiyasının leksik problemləri”, Bak1, "Maarif", 1997, $253 \mathrm{~s}$.

[4] Н.А.Баскаков, “Русские фамилии тюркского происхождения”, Баку, "Язычы", 1992, 280 с.

[5] M.N.Çobanov, "Azərbaycan antroponimiyasının əsasları", Bakı, "Maarif", 1998, 332 s.

[6] Fərəcov N.R. Familiyalarımızın taleyinə dair mülahizələr/Azərbaycan dilinin etimologiya və onomastikası məsələləri. Bakı, BDU nəşriyyatı, 1990, s. 96-100

[7] Y.Cəfərov, “Azərbaycan dilinin onomastikası müstəqillik dövründə”, Bakı, "Elm və təhsil" nəşriyyatı, 2015, 367 s.

[8] “Adlar və Soyadlar" Dövlət İnformasiya Sisteminin yaradılması Konsepsiyası. AMEA İnformasiya Texnologiyaları İnstitutu, Ekspressİnformasiya, Bak1, 2010, 49 s.

[9] Azərbaycan Respublikası Nazirlər Kabinetinin Qərarı, Bakı şəhəri, 12 may 2011-ci il, //www.e-qanun.az/framework/21676.

[10] The Use of Middle Names, www.genfiles.com/articles/middle-names/

[11] az.wikipedia.org. "Pasport".

[12] Machine Readable Travel Documents, Seventh Edition, 2015, Part 3: Specifications Common to all MRTDs, ICAO, $86 \mathrm{p}$

\section{ABOUT ISSUES OF IDENTIFICATION OF THE CITIZENS OF AZERBAIJAN IN INFORMATION SOCIESTY AND WAYS OF THEIR SOLUTION}

Rasim Alguliyev $^{1}$, Yedgar Jafarov ${ }^{2}$, Afruz Gurbanova ${ }^{3}$

Institute of Information Technology of ANAS, Baku, Azerbaijan

Idirector@iit.science.az, ${ }^{2} y e d g a r @ y a n d e x . r u$, 3afruz1961@gmail.com

Abstract - The article is devoted to the issues of the naming system and national identity. Attention is paid to the current name problems in Azerbaijan. The article considers negative cases caused by these problems in the era of globalization and the information society environment. A wide scientific analysis of Azerbaijani names and surnames, historical traditions in this field, names structure and so on is carried out. Specific proposals are given in order to solve these problems.

Key words - name, surname, patronymic, nickname, naming system, national identit 